Standard Conditions for the Assessment of Colour (3 p.m.) Mr C. R. Bullett, Mr J. E. Cotton, Mr I. Glasman and Mr D. G. C. Thornley, Colour Group (Great Britain), in the Mechanical Engineering Department, Imperial College, Exhibition Road, London SW7.

The Expansion of the Fisheries: The Application of Mechanical Power in Man's Oldest Industry (6 p.m.) $\mathrm{Mr}$ G. C. Eddie, Institution of Mechanical Engineers, at 1 Birdcage Walk, London SW1. (James Clayton Lecture.)

The Problems of Painting Timber (4.30 p.m.) Mr G. W. Rothwell, Oil and Colour Chemists' Association, at the Manchester Literary and Philosophical Society, 36 George Street, Manchester 1. (Student Lecture.)

The Use of Telecommunications in Meteorology (5.30 p.m.) Mr A. A. Worthington, Institution of Electrical Engineers, at Savoy Place, London WC2.

\section{Reports and Publications}

not included in the Monthly Books Supplement

\section{Great Britain and Ireland}

Philosophical Transactions of the Royal Society of London. B: Biological Sciences. Vol. 259, No. 833 (11 February 1971): The Corpora Pedunculata of Sphinx Ligustri L. and other Lepidoptera: an Anatomical Study. By Lucy Pearson. Pp. 477-516 +plates $31-35$. \&1.50; $\$ 3.90$. Vol. 259, No. 834 (11 February 1971): Observations on the Structure of the Small Intestine in Foetal, Neo-Natal and Suckling Pigs. By R. N. Hardy, A. R. Hockaday and R. L. Tapp. Pp.
$517-531+$ plates. $36-42$. $£ 0.95 ; \$ 2.45$. (London: $517-531+$ plates $36-42$,
The Royal Society. 197i.) The Royal Society. 1971.) A Guide to the Literature on Spectral Data. By
A. Clarke. Pp. 11. (London: National Reference A. Clarke. Pp. 11. (London: National Reference National Economic Development Office. Qualified Manpower in the Electronics Industry - A Preliminary Report. (Report of the Electronics EDC Working Group on Scientific and Technological Manpower.)
Pp. xii + 44. (London: National Economic Develop-
ment Office, 1971.)

A Proposed Programme of Support for the Physics of A Proposed Programme of Support for the Physics of Surfaces. Pp.
1971.) gratis.

1971.) gratis.
Philosophical Transactions of the Royal Society of London. B: Biological Sciences. Vol. 260, No. 836 (4 March 1971): A Discussion on the Results of the Royal Society Expedition to Aldabra 1967-68, Organized by T. S. Westoll and D. R. Stoddart. Pp. 1-654. (London: The Royal Society, 1971.) £19; \$50. $\quad[83$ University of Essex Vice-Chancellor's Report 1969/1970. Pp. 45+xxxiii. (Wivenhoe Park, Col-
[93 chester: University of Essex, 1971.) Survey No. 9: Diagnostic and Assessment Units for Young Handicapped Children. Pp. iii-19. (London: HMSO, 1970.) 20p net.

Imperial College. Annual Report 1969/1970. Pp. iv +98. Annual Accounts 1969/1970. Pp. 31. (Lon-

\title{
Notes to Authors
}

Will contributors to Nature follow as far as possible the general style of the journal, and in particular the following rules:

1. Manuscripts should be typed in double spacing and submitted in duplicate. Two copies of all figures should be included, one for the printers and one for the referee.

2. References are indicated by superscript numbers in the order in which they appear in the text, and have the following form :

${ }^{1}$ Sargent, W. L. W., and Searle, L., Astrophys. J. Lett., 162, L155 (1970).

${ }^{2}$ Fraenkel-Conrat, H., in Comprehensive Biochemistry (edit. by Florkin, M., and Stotz, E. H.), 7, 75 (Elsevier, Amsterdam, 1963).

"Unpublished work", "Private communication" and "Work in preparation" should not be cited as references but may be incorporated in the text. Each reference number should refer to an individual work which has either been published or is in the press.

3. Although the text of longer articles is usually interrupted by headings at suitable intervals, these should be short and informative and not merely "Introduction", "Results", or "Conclusion".

4. Units should either conform to the SI system or be spelled out in full.

A fuller guide can be had from the Nature offices in London and Washington. don: Imperial College of Science and Technology,
University of London, 1971.)

Department of Education and Science. Statistics of Education 1969, Vol. 2: School Leavers. GCE and CSE. Pp. xxv +88. (London: HMSO, 1971.) $£ 1.60$ net.

Conference on Electrical Safety in Hazardous Environments, 16/18 March 1971. Pp. 185. (London Institution of Electrical Engineers, 1971.) [103 Teacher Training: Opportunities for Science, Technology and Mathematics Graduates. Pp. 86. (London: The Royal Society, 1971.)

Greenwich Time Report. Royal Greenwich Observatory-Time and Latitude Service, 1970 April-June Pp. 139-150. (London: Science Research Council,
1971.) 1971.)
Water Resources Act, 1963. Seventh Annual Report of the Water Resources Board for the year ending 30th September 1970. Pp. viii + 103. (London: HMSO 1971.) 70 p net.
Local Government Elections 1971-Campaign Guide. Pp. 84. (London: Conservative Central Office, 1971.) Scientific Proceedings of the Royal Dublin Society. Series A. Vol. 3, No. 29: Stratigraphy of some Metasediments in Part of North-west County Mayo, Ireland. By Michael D. Max. Pp. 303-318 + plate 12. 9s. Vol. 3, No. 30: Notes on Alternating Temperatures and Adult Lifespan in Acanthocyclops viridis. By J. N. R. Grainger and M. F. Khan. Pp. 319-322. 4s. Dublin. By P. M. Brilck and P. Kennan. Pp. 323-334 + plate 13. 7s. Vol. 3, No. 32: Monograptus Ludensis Zone Graptolites from the Devilsbit Mountain District, Tipperary. By D. Palm Pp. 335-342 + plates 14 and 15. 8s. Vol. 3, No. 33 Palynological Evidence for the Age of the Old Red Sandstone neat Cappagh White, Co. Tipperary. By R. J. P. Doran. Pp. 343-350+plate 16. 8s. Series B. Vol. 2, No. 26: A Study of the Utilization of (2-Chloroethyl) Trimethylammonium Chloride (Chlorocholine Chloride; CCC) Under Irish Conditions, II. By E. J. Gallagher. Pp. 263-274. 6s. Vol. 2, No. 27: Peroxidase in Barley Endosperm as a Bioassay for Gibberellins. By Ann Murray and M. A. Harmet. Pp. 275-282. 6s. Walsh. Pp. 283-284. 2s. Vol. 2, No. 29: Boyle
Medal Lecture - Towards Efficiency in the Use of Our Soils. By Thomas WaJsh. Pp. 285-328. 15s. (Dublin: Royal Dublin Society, 1970.) The Three-Dimensional Analysis of Meteorological Data. By R. Dixon and E. A. Spackman. Pp. 28. $37 \frac{1}{2}$. Scientific Paper No. 32: The Bushby-Timpson Benwell, A. J. Gadd, J. F. Keers, Margaret S. Timpson and P. W. White. Pp. 50. 551 p. (London: HMSO, 1970 and 1971.)

Department of Employment. Safety in the Use of Abrasive Wheels. (Health and Safety at Work. No. 4.) Pp. 65. (London: HMSO, 1971.) 271p net. [123 University of Edinburgh. Report on Laboratory
Design. Pp. 52. (Edinburgh: The University. Design.

\section{Other Countries}

Bulletin of the Auckland Institute and Muscum. No. 8: Systematics of the Families Mitridae and Volutomitridae (Mollusca: Gastropoda). By Walter O. Cernohorsky. Pp. 190. (Auckland: Auckland Institute and Museum, 1970.) World Health Organization. Technical Report Series. No. 455: Treponematoses ResearchReport of a WHO Scientific Group. Pp. 91. 5 Sw. francs ; 50p : \$1.75. No. 459: WHO Expert Committec on Leprosy-Fourth Report. Pp. 31. 3 Sw. francs : 30p: $\$ 1$. No. 460: WHO Expert Committce on Drug Dependence-Eighteenth Report. Pp. 45. 2 Sw. francs; 30p ; \$1. (Geneva: WHO ; London: HMSO, 1970.) [181 US Department of the Interior: Geological Survey. Professional Paper 576-C: Structure of the Slick Rock District and Vicinity, San Miguel and Dolores Counties, Colorado. By Daniel R. Shawe. Pp. iii + 18. \$0.35. Professional Paper 599-E: A Photoelectric-Photographic Study of the Normal Aboedo of the Moon. By Howard A. Pohn and Robert L. Wildey, Pp. iii $+20+1$ plate. Professional Paper 641-B: Gneissic and Igneous Rocks of the Quadrilatero Ferrifero, Minas Gerais, Brazil. By Norman Herz. $\mathrm{Pp}$. iv +58 , \$1; (Washington, DC:

\section{HOW TO BUY NATURE}

Volumes start in January, March, May, July, September and November, but subscriptions may begin at any time.

The direct postal price per subscription is:

12 MONTHS * (52 issues per title)

\begin{tabular}{|c|c|c|c|}
\hline \multirow{2}{*}{\multicolumn{2}{|c|}{$\begin{array}{c}\text { Surface Mail } \\
\text { UK and } \\
\text { worldwide }\end{array}$}} & \multicolumn{2}{|c|}{ Airfreight } \\
\hline & & U.S.A. & Canada \\
\hline Nature (Friday) & $£ 14$ & $\$ 48$ & $\$ 52$ \\
\hline $\begin{array}{l}\text { Nature }+ \\
\text { Nature Physical Science }\end{array}$ & $£ 24$ & $\$ 83$ & $\$ 90$ \\
\hline $\begin{array}{l}\text { Nature }+ \\
\text { Nature New Biology }\end{array}$ & $\varepsilon 24$ & $\$ 83$ & $\$ 90$ \\
\hline All three editions & $£ 29.50$ & $\$ 108$ & $\$ 116$ \\
\hline Annual Index & E1 & $\$ 3$ & $\$ 3$ \\
\hline
\end{tabular}

* Rates for shorter periods pro rata (minimum three months) (Charge for delivery by air mail on application)
Editorial and Publishing Offices of NATURE

MACMILLAN JOURNALS LIMITED

4 LITTLE ESSEX STREET, LONDON WC2R 3LF

Telephone Number: 01-836 6633. Telegrams: Phusis London WC2R 3LF

711 NATIONAL PRESS BUILDING

WASHINGTON DC 20004

Telephone Number: 202-737 2355

Subscription Department

MACMILLAN JOURNALS LIMITED

BRUNEL ROAD, BASINGSTOKE, HANTS

Telephone Number: Basingstoke 5431

Advertisements only should be addressed to

T. G. SCOTT \& SON, LIMITED

1 CLEMENT'S INN, LONDON WC2A 2ED

Telephone 01-242 6264/01-405 4743

Telegrams: Textualist London WC2A 2ED

Registered as a newspaper at the Post Office

Copyright (C) Macmillan Journals Limited, April 21971 